\title{
Analisis Pelaksanaan Pembelajaran Daring Pada Masa Pandemi Covid-19 di Sekolah Dasar
}

\author{
Halimatusadiya*, Ririn Andriani Kumala Dewi, Khoimatun \\ Program Studi PGSD STKIP Nahdlatul Ulama Indramayu, Indonesia \\ *Coresponding Author: halimatusadiya266@gmail.com
}

\begin{abstract}
The existence of the Covid-19 pandemic requires the government to issue a circular explaining that the implementation of learning is carried out at home through online learning. In order for online learning to take place well, learning must be planned, implemented and evaluated by the teacher so that learning objectives are still achieved even though learning is carried out online. This study aims to describe the implementation of online learning, find out the problems that arise and the solutions taken to solve online learning problems during the Covid-19 pandemic in elementary schools. The research method used is a qualitative method, with the type of phenomenological research. The data collection technique in this study used observation and interview techniques with data sources from teachers, students and guardians of students. The data analysis technique uses the stages of data reduction, data presentation, and drawing conclusions. Based on the results of observations of $85.35 \%$, it shows that the implementation of learning at SDN 1 Kedokan Agung during the covid-19 pandemic has been carried out very well, teachers and students already have the basic facilities needed, this shows the readiness for the implementation of online learning. The implementation of online learning causes problems such as the lack of enthusiasm of students in learning, the lack of cooperation between parents and students and limited facilities. The solutions taken to solve online learning problems include teachers continuing to provide guidance and assistance to students, providing an understanding of the importance of collaboration between parents and students.
\end{abstract}

Keywords: analysis; online learning; covid-19 pandemic; elementary school

Article History:

Received 2022-01-17

Revised 2022-02-22

Accepted 2022-03-01

DOI:

10.31949/educatio.v8i1.1888

\section{PENDAHULUAN}

Menurut Undang-Undang Sistem Pendidikan Nasional Nomor 20 Tahun 2003 menjelaskan bahwa Pendidikan adalah usaha sadar dan terencana untuk mewujudkan suasana belajar dan proses pembelajaran 
agar peserta didik secara aktif mengembangkan potensi dirinya untuk memiliki kekuatan spiritual keagamaan, pengendalian diri, kepribadian, kecerdasan, akhlak mulia, serta keterampilan yang diperlukan dirinya, masyarakat, bangsa dan negara.

Pada tanggal 24 Maret, Menteri Pendidikan dan Kebudayaan Republik Indonesia mengeluarkan surat edaran Nomor 4 Tahun 2020 tentang pelaksanaan kebijakan pendidikan dalam masa darurat penyebaran Covid-19, dalam surat edaran tersebut dijelaskan bahwa proses pembelajaran dilaksanakan di rumah melalui pembelajaran daring/jarak jauh. Hal tersebut dilakukan untuk mencegah penyebaran virus corona, dan untuk memperkuat surat edaran ini Kementrian Pendidikan dan Kebudayaan Republik Indonesia menerbitkan Surat Edaran Nomor 15 Tahun 2020 tentang pedoman penyelenggaraan belajar dari rumah dalam masa darurat penyebaran Covid-19.

Adanya pandemi Covid-19 menuntut lembaga pendidikan untuk melakukan inovasi dalam proses pembelajaran. Salah satu bentuk inovasi tersebut adalah dengan melakukan Pembelajaran Jarak Jauh (PJJ). Dalam Undang-Undang No. 20 tahun 2003 pasal 1 ayat 15, dijelaskan bahwa pendidikan jarak jauh adalah pendidikan yang peserta didiknya terpisah dari pendidik dan pembelajarannya menggunakan berbagai sumber belajar melalui teknologi komunikasi, informasi dan media lain. Metode dan media pelaksanaan belajar dari rumah dengan Pembelajaran Jarak Jauh (PJJ) yang dibagi kedalam dua pendekatan, yaitu pembelajaran jarak jauh dalam jaringan (daring) dan pembelajaran jarak jauh luar jaringan (luring). Dalam pelaksanaannya, satuan pendidikan dapat memilih pendekatan sesuai dengan karakteristik dan ketersediaan, kesiapan sarana dan prasarana (Asmuni, 2020).

Dari paparan di atas, salah satu pendekatan dalam PJJ adalah pembelajaran daring. Pembelajaran daring adalah suatu bagian dari pembelajaran jarak jauh yang secara khusus pembelajaran menggabungkan teknologi elektronik dan internet (Asmuni, 2020). Menurut Bilfaqih \& Qomarudin (2015:1), pembelajaran daring merupakan program penyelenggaraan kelas pembelajaran dalam jaringan untuk menjangkau kelompok target yang masif dan luas melalui jaringan internet. Sejalan dengan Moore, Dickson-Deane, \& Galyen (Sadikin \& Hamidah, 2020:215) pembelajaran daring adalah pembelajaran yang menggunakan aksebilitas, konektivitas, fleksibilitas dan kemampuan untuk memunculkan berbagai jenis interaksi dalam sebuah pembelajaran.

Pembelajaran daring merupakan sebuah tantangan baru bagi para guru di masa pandemi ini, yang mengharuskan para guru mampu menggunakan media pembelajaran online, untuk dapat melaksanakan pembelajaran secara online dan diharapkan mampu meningkatkan kreativitasnya dalam proses pembelajaran. Untuk melaksanakan pembelajaran daring, seluruh pihak yang ikut berperan dalam proses pembelajaran harus memiliki kesiapan seperti jaringan internet dengan konektivitas yang memadai serta fasilitas lainnya yang dapat menunjang agar proses pembelajaran secara daring dapat dilaksanakan dengan baik dan efektif. Pembelajaran daring bukan sekedar materi yang dipindah melalui media internet, bukan juga sekedar tugas dan soal-soal yang dikirimkan melalui aplikasi sosial media. Pembelajaran daring harus direncanakan, dilaksanakan, serta dievaluasi sama halnya dengan pembelajaran yang terjadi di kelas.

Dari hasil observasi dan wawancara dengan salah satu guru di SD Negeri 1 Kedokan Agung diperoleh hasil temuan bahwa pelaksanaan pembelajaran secara daring di sekolah tersebut sudah terlaksana, pada pembelajaran daring di kelas biasanya guru menggunakan whatsapp group. Selain itu, guru melakukan persiapan sebelum pelaksanaan pembelajaran berlangsung. Guru juga membuat video pembelajaran sebagai media bagi peserta didik untuk menjelaskan materi pembelajaran dengan didukung fasilitas yang menunjang pembelajaran daring. Berdasarkan uraian di atas dapat dilakukan penelitian mengenai "Analisis Pelaksanaan Pembelajaran Daring Pada Masa Pandemi Covid-19 di Sekolah Dasar".

Tujuan dari penelitian ini adalah untuk mendeskripsikan pelaksanaan pembelajaran daring, mengetahui problematika yang muncul, serta mengetahui solusi yang ditempuh untuk menyelesaikan permasalahan pembelajaran daring pada masa pandemi Covid-19 di SD Negeri 1 Kedokan Agung.

\section{METODE PENELITIAN}

Penelitian ini bertujuan untuk mendeskripsikan mengenai hasil penelitian yang membahas tentang pelaksanaan pembelajaran daring pada masa pandemi Covid-19 di Sekolah Dasar. Pendekatan yang digunakan 
pada penelitian ini adalah pendekatan Kualitatif, dengan jenis penelitian fenomenologi. Penelitian ini dilakukan di SD Negeri 1 Kedokan Agung yang bertempat di Jl. Raya Kedokan No. 15, Kedokan Agung, Kecamatan Kedokanbunder Kabupaten Indramayu. Waktu penelitian dilaksanakan pada semester 1 (ganjil) tahun pelajaran 2021/2022. Teknik pengumpulan data pada penelitian ini menggunakan teknik observasi dan wawancara dengan sumber data guru, peserta didik dan wali murid. Adapun teknik analisis data yang digunakan pada penelitian ini adalah teknik analisis data model Miles and Huberman (Sugiyono, 2020:321) yaitu reduksi data, penyajian data, serta pengambilan kesimpulan.

\section{HASIL DAN PEMBAHASAN}

Pembelajaran daring di SD Negeri 1 Kedokan Agung mulai dilaksanakan pada bulan maret 2020. Pelaksanaan pembelajaran daring didasari dari adanya surat edaran tentang larangan tatap muka yang dikeluarkan oleh Kementerian Pendidikan dan Kebudayaan (Kemendikbud). Menurut Bilfaqih dan Qomaruddin (dalam Asmuni, 2020) pembelajaran daring adalah pembelajaran yang menggunakan model interaktif berbasis internet dan Learning Manajemen System (LMS). Pembelajaran daring merupakan program penyelenggaraan kelas pembelajaran dalam jaringan untuk menjangkau kelompok target yang masif dan luas. Adapun hasil penelitian yang diperoleh dalam penelitian ini adalah

Tabel 1. Rekapitulasi Hasil Observasi Pelaksanaan Pembelajaran Daring

\begin{tabular}{ccc}
\hline Jumlah & Persentase & Kategori \\
\hline 281,67 & 85,35 & Sangat baik \\
\hline
\end{tabular}

Berdasarkan tabel 1 diperoleh hasil observasi sebesar 85,35\% yang menunjukkan bahwa pelaksanaan pembelajaran daring di SD Negeri 1 Kedokan Agung sudah terlaksana dengan sangat baik, guru sudah melakukan perencanaan pembelajaran dan sudah melaksanakan pembelajaran dengan membuat RPP daring, mempersiapkan materi, media, menggunakan metode dan pendekatan pembelajaran yang disesuaikan dengan karakteristik peserta didik, serta melaksanakan evaluasi akhir sesuai dengan kompetensi peserta didik. Namun, beberapa guru masih belum menyampaikan kompetensi dasar yang akan dicapai dalam pembelajaran kepada peserta didik dan masih belum mengenal karakteristik peserta didiknya.

Hal yang dilakukan sekolah pada saat pelaksanaan pembelajaran di rumah ialah membuat jaringan komunikasi untuk menghubungkan peserta didik dan sekolah dengan memanfaatkan salah satu aplikasi komunikasi yaitu whatsapp. Whatsapp dipilih karena dirasa paling efektif dan mudah untuk digunakan, jaringan komunikasi dibuat berbentuk whatsapp group berbasis kelas, yang didalamnya terdapat guru kelas beserta peserta didik.

Dalam pelaksanaan pembelajaran ditengah kondisi pandemi covid-19 tentunya akan berbeda dengan kondisi biasanya. Pembelajaran daring pada dasarnya adalah pembelajaran yang dilaksanakan secara virtual melalui aplikasi virtual yang tersedia, meski demikian pembelajaran secara daring harus tetap memperhatikan kompetensi yang hendak disampaikan dan diajarkan kepada peserta didik. Pembelajaran berbasis daring menggunakan koneksi internet merupakan satu-satunya media penyampai materi yang digunakan oleh guru dan peserta didik dalam proses pembelajaran di masa pandemi (Imania \& Bariah, 2019).

Pembelajaran daring bukan hanya pembelajaran yang memindahkan materi melalui media internet, dan guru bukan hanya sekedar memberikan tugas dan soal-soal yang dikirimkan melalui aplikasi sosial media (online), pembelajaran daring harus tetap dipersiapkan, dilaksanakan, serta dievaluasi sama halnya dengan pembelajaran tatap muka. Dengan pembelajaran daring peserta didik memiliki keleluasaan waktu belajar, dapat belajar kapanpun dan di manapun. Pembelajaran ini merupakan inovasi pendidikan untuk menjawab tantangan akan ketersediaan sumber belajar yang variatif (Dewi, 2020).

Pelaksanaan pembelajaran daring di SD Negeri 1 Kedokan Agung, kab. Indramayu sudah berjalan dengan lancar. Salah satu guru (Guru I) mengatakan bahwa sebelum pelaksanaan pembelajaran daring berlangsung, setiap guru sudah melakukan perencanaan pembelajaran dengan membuat RPP, mempersiapkan 
materi dan media pembelajaran. Sedangkan guru lain (Guru II) mengatakan bahwa pada saat pelaksanaan pembelajaran daring guru juga harus menggunakan metode dan pendekatan pembelajaran yang disesuaikan dengan karakteristik peserta didik serta melaksanakan evaluasi akhir sesuai dengan kompetensi peserta didik.

Berdasarkan hasil observasi dan wawancara, terlihat setiap guru dalam pembelajaran daring melakukan perencanaan pembelajaran agar dalam proses belajar mengajar menjadi lebih terarah. Tahap perencanaan pembelajaran yang dilakukan guru yaitu membuat RPP daring dengan melihat internet dan berdiskusi dengan guru lain, RPP daring yang dibuat guru terdiri dari kegiatan awal, kegiatan inti, dan kegiatan akhir. Menurut Bararah (2017: 132) RPP adalah rancangan pembelajaran mata pelajaran per unit yang akan diterapkan guru dalam pembelajaran dikelas. Selain itu, guru selalu mempersiapkan bahan ajar berupa materi pelajaran yang akan diajarkan kepada peserta didik dengan mempelajari kembali materi, hal itu dilakukan agar pada saat proses pembelajaran berlangsung guru dapat menguasai semua materi pelajaran. Menurut Syarifudin (2020: 32) materi pembelajaran daring juga harus tetap mempertimbangkan teori kontruktivisme yang menjadikan peserta didik berperan aktif. Guru juga sudah mempersiapkan dan membuat media pembelajaran berupa video pembelajaran yang disesuaikan dengan materi yang akan dipelajari sebelum pelaksanaan pembelajaran daring berlangsung. Menurut Tafonao (2018:105) media pembelajaran adalah alat bantu dalam proses belajar mengajar untuk merangsang pikiran, perasaan, perhatian dan kemampuan atau ketrampilan pembelajar sehingga dapat mendorong terjadinya proses belajar. Biasanya guru akan membagikan atau mengirimkan link video pembelajaran dari youtube tersebut ke whatsapps grup, penggunaan media pembelajaran ini bertujuan untuk mempermudah peserta didik dalam memahami materi pembelajaran yang disampaikan guru nantinya. Perencanaan pembelajaran merupakan komponen paling penting dalam pelaksanaan pembelajaran, dengan adanya perencanaan yang baik maka pelaksanaan pembelajaran akan menjadi lebih terarah dan sistematis.

Berdasarkan hasil observasi dan wawancara, peserta didik sudah cukup baik, mereka mempersiapkan segala sesuatu yang dibutuhkan dalam pembelajaran daring seperti buku, pensil, bandphone atau laptop yang dibantu oleh orang tua mereka dalam mempersiapkan semuanya. Begitu juga dengan guru yang telah melakukan persiapan dalam pembelajaran daring, mereka mengikuti pelatihan yang diselenggarakan di sekolah sehingga guru dapat belajar menggunakan media elektronik. Pelatihan ini bertujuan untuk membekali guru dalam melaksanakan pembelajaran daring, sehingga guru tidak gagap teknologi dalam pelaksanaan pembelajaran daring. Menurut Sopian (2016:96) guru dalam melaksanakan tugasnya harus memiliki seperangkat kemampuan di bidang yang akan disampaikan serta harus memiliki penguasaan materi agar mudah diterima peserta didik yang meliputi kemampuan mengawasi, melatih serta memiliki keterampilan profesional dan sosial.

Peran orang tua sangat di perlukan untuk proses pembelajaran anak selama belajar di rumah, peran orang tua juga sangat diperlukan untuk memberikan edukasi kepada anak yang masih belum memahami tentang pandemi yang dialami saat ini sehingga menyebabkan semua orang untuk tetap berdiam diri di rumah agar tidak tertular dan menularkan wabah virus Covid 19 (Cahyati \& Rita, 2020).

Pendekatan dan metode pembelajaran harus berdasarkan kebutuhan virtual, karena tidak semua metode konvensional dapat digunakan dalam pembelajaran daring, sehingga perlu dilakukan modifikasi terlebih dahulu. Dalam pelaksanaan pembelajaran daring ketersediaan sarana dan prasarana merupakan hal utama untuk menunjang keberhasilan pelaksanaan pembelajaran daring. Pada pelaksanaan pembelajaran daring ini peserta didik lebih suka menggunakan handphone karena dianggap lebih praktis. Sekolah juga telah memberikan fasilitas berupa buku paket dan fasilitas lainnya yang dibutuhkan oleh guru.

Berdasarkan hasil observasi dan wawancara, guru melaksanakan evaluasi dan penilaian sesuai dengan kompetensi peserta didik mengenai keaktifan dan kedisiplinan peserta didik dalam mengumpulkan tugas. Penilaian merupakan salah satu hal penting dalam pembelajaran untuk mengetahui ketercapaian peserta didik dalam pembelajaran. Selain itu dengan adanya penilaian akan memotivasi peserta didik untuk terus belajar sehingga mendapatkan nilai yang memuaskan.

Problematika pembelajaran adalah permasalahan yang mengganggu dan menghambat atau mempersulit proses pencapaian tujuan dan jalannya pembelajaran. Dari hasil penelitian (Rigianti, 2020) mengenai kendala dalam pembelajaran daring pada guru sekolah dasar di kabupaten Banjarnegara menjelaskan bahwa perubahan 
pembelajaran tatap muka menjadi pembelajaran daring memberikan berbagai macam kendala dalam pendidikan terutama terhadap guru yang menjadi ujung tombak dalam pelaksanaan pembelajaran.

Adanya problematika yang muncul dalam pelaksanaan pembelajaran daring di SD Negeri 1 Kedokan Agung, Kab. Indramayu menyebabkan pembelajaran secara daring menjadi tidak efektif. Salah satu guru (guru III) mengatakan bahwa tidak semua wali murid mempunyai handphone, masalah kuota internet dan sinyal yang tidak stabil. Sedangkan guru lain (guru IV) mengatakan bahwa guru tidak bisa memantau secara langsung kemampuan anak, kurangnya motivasi belajar anak, tingkat pemahaman yang berbeda-beda serta orang tua yang sibuk bekerja sehingga tidak bisa mendampingi dan mengawasi anak-anaknya belajar di rumah. Salah satu peserta didik I mengatakan bahwa dalam pelaksanaan pembelajaran daring, terkadang ia kurang memahami materi yang diberikan guru sehingga harus dijelaskan kembali oleh orang tuanya. Sedangkan peserta didik II mengatakan bahwa terkadang tidak ada penjelasan materi dari guru, guru hanya memberikan tugas dan guru tidak memberikan penilaian/komentar selama pembelajaran. Lalu hasil wawancara dengan wali murid I mengatakan tidak adanya waktu orang tua untuk mendampingi anak pada saat pembelajaran daring karena harus bekerja, orang tua merasa anak lebih banyak bermain dibandingkan belajar serta adanya biaya tambahan untuk pembelian kuota. Sedangkan wali murid II mengatakan bahwa ia tidak memiliki handphone sebagai media penunjang pembelajaran dan tidak mengerti apa yang dikerjakan anaknya.

Berdasarkan hasil observasi dan wawancara di SD Negeri 1 Kedokan Agung, Kab. Indramayu menunjukkan adanya problematika pada pelaksanaan pembelajaran daring yang dialami oleh guru, diantaranya adalah adanya keterbatasan kemampuan dan fasilitas yang menimbulkan penyampaian materi hanya dapat dilakukan dengan aplikasi Whats $A p p$, tidak stabilnya jaringan internet, tingkat pemahaman yang berbeda-beda, anak kurang aktif dalam mengikuti pembelajaran, orang tua yang sibuk bekerja tidak dapat memdampingi anaknya pada saat pelaksanaan pembelajaran daring berlangsung sehingga mempengaruhi semangat ataupun kedisiplinan anak, tidak semua siswa memiliki fasilitas yang memadai untuk menunjang pelaksanaan pembelajaran daring. Problematika pelaksanaan daring sesungguhnya tidak hanya dirasakan oleh guru, namun peserta didik yang terlibat dalam proses pembelajaran juga tidak dapat menghindari adanya permasalahan yang muncul. Problematika yang dialami siswa yaitu, kurang memahami materi yang diberikan guru, koneksi internet yang tidak stabil, terkadang tidak ada penjelasan materi dari guru, guru hanya memberikan tugas dan guru tidak memberikan penilaian/komentar selama pembelajaran. Selain menimbulkan problematika pada guru dan peserta didik, pembelajaran daring juga memberikan permasalahan baru pada wali murid. Problematika yang dialami wali murid yaitu tidak adanya waktu orang tua untuk mendampingi anak pada saat pembelajaran daring karena harus bekerja, orang tua merasa anak lebih banyak bermain dibandingkan belajar serta adanya biaya tambahan untuk pembelian kuota.. Sedangkan wali murid lain mengatakan bahwa ia tidak memiliki handphone sebagai media penunjang pembelajaran dan tidak mengerti apa yang dikerjakan anaknya.

Problematika pelaksanaan pembelajaran daring ini sesuai dengan apa yang di sampaikan oleh (Asmuni, 2020) pada penelitiannya, problematika pembelajaran daring di masa pandemi Covid-19 antara lain faktor yang berasal dari guru, materi yang disampaikan oleh guru secara daring belum tentu dapat dipahami oleh peserta didik, adanya keterbatasan guru dalam menggunakan teknologi penunjang pembelajaran daring, guru yang tidak dapat melakukan melakukan kontrol secara penuh terhadap peserta didik ketika pembelajaran daring berlangsung. Kemudian faktor yang berasal dari peserta didik yaitu, kurang aktif dan tertariknya peserta didik dalam mengikuti pembelajaran daring, tidak semua peseta didik memiliki perangkat atau media yang dapat menunjang pembelajaran daring, tidak adanya akses internet. Selain faktor guru dan peserta didik, terdapat faktor yang berasal dari orang tua antara lain, kondisi perekonomian orang tua peserta didik, tidak semua orang tua dapat mendampingi anaknya dalam proses pembelajaran daring, dan adanya pembengkakan pengeluaran orang tua guna menunjang proses pembelajaran daring.

Dari problematika pelaksanaan pembelajaran daring yang muncul, terdapat solusi yang ditempuh untuk menyelesaikan permasalahan, sebagaimana guru $\mathrm{V}$ mengatakan bagi wali murid yang tidak memiliki handphone ataupun terkendala jaringan, peserta didik bisa langsung datang ke sekolah. Sedangkan guru VI mengatakan bahwa ia meminta kerjasama dan memberitahukan wali murid agar bisa mengawasi dan membantu pelaksanaan pembelajaran daring. Sebagian besar wali murid juga menyatakkan selalu memberi motivasi dan 
nasihat kepada anaknya agar tetap konsisten dan semangat dalam belajar, memberikan apresiasi berupa pujian maupun iming-iming hadiah.

Berdasarkan hasil observasi dan wawancara yang dilakukan dengan guru, upaya yang dilakukan dalam mengatasi problematika pelaksanaan pembelajaran daring yaitu apabila ada orang tua atau siswa yang tidak memiliki handphone bisa bertanya dan datang langsung ke sekolah terkait informasi maupun penugasan, guru memberikan pemahaman kepada wali murid tentang pentingnya kerjasama wali murid dalam mengawasi putra-putrinya belajar dari rumah, karena pengendalian dan pengawasan wali murid sangat penting pada saat pelaksanaan pembelajaran daring saat ini, serta guru tetap memotivasi peserta didik agar tetap semangat belajar meskipun dari rumah, memberikan bimbingan dan pendampingan pada peserta didik baik secara berkelompok atau individual. Untuk upaya yang dilakukan siswa dalam mengatasi kendala yang dialami dengan mengulangi materi yang ada agar dapat memahami, mencari tempat yang sekiranya sinyal lancar atau stabil. Sedangkan upaya yang dilakukan orang tua dalam mengatasi problematika pembelajaran daring yang sedang dijalankan anaknya hanya sebatas memenuhi kebutuhan yang diperlukan anaknya untuk menunjang pembelajaran daring.

Persiapan maksimum harus dibuat oleh guru sehingga peserta didik belajar dengan senang hati dan tetap tinggal di rumah. Lebih lanjut, umpan balik terhadap tugas yang dikerjakan oleh peserta didik haruslah tetap diberikan oleh guru agar peserta didik merasa dihargai. Komentar atau tanggapan yang diberikan oleh guru dapat membantu peserta didik memahami kekurangan dan kelebihan mereka (Firman \& Rahayu, 2020). Penelitian ini sejalan dengan penelitian yang dilakukan (Asmuni, 2020). Hasil penelitian beliau menunjukkan, adanya upaya meningkatkan kompetensi penguasaan IT, pengawasan intensif dengan melibatkan peran orangtua, dan memberikan penugasan secara manual.

Menurut Hattie (Rupiah, 2020) menyebutkan bahwa hasil pembelajaran dapat ditingkatkan melalui timbal balik guru dan peserta didik. Selain itu perlu adanya pendampingan kepada peserta didik secara khusus yang dibatasi oleh akses internet, seperti jadwal kerja yang lebih fleksibel dan penerapan pembelajaran gabungan (tatap muka). Jika hal tersebut diimplementasikan dengan baik, maka hasil pembelajaran secara daring dapat terlihat secara maksimal. Artinya, guru dapat memberikan pembelajaran baik secara daring/luring dan peserta didik memahami materi yang disampaikan. Hal ini sejalan dengan pendapat Dewi (2020) untuk wali murid yang bekerja sehingga tidak bisa mendampingi anak saat belajar dapat memberikan jadwal-jadwal belajar khusus agar bisa belajar seperti peserta didik yang lainnya. Jadi, adanya kerjasama dan timbal balik antara guru, peserta didik dan wali murid yang menjadikan pembelajaran daring menjadi efektif.

\section{KESIMPULAN}

Berdasarkan tabel rekapitulasi hasil observasi diperoleh sebesar 85,35\% yang menunjukkan bahwa pelaksanaan pembelajaran daring di SD Negeri 1 Kedokan Agung tahun pelajaran 2021/2022 sudah terlaksana dengan sangat baik, guru sudah melakukan perencanaan pembelajaran dan melaksanakan pembelajaran dengan membuat RPP daring, mempersiapkan materi, media, menggunakan metode dan pendekatan pembelajaran yang disesuaikan dengan karakteristik peserta didik, serta melaksanakan evaluasi akhir sesuai dengan kompetensi peserta didik. Namun, beberapa guru masih belum menyampaikan kompetensi dasar yang akan dicapai dalam pembelajaran kepada peserta didik dan masih belum mengenal karakteristik peserta didiknya. Problematika yang muncul dalam pelaksanaan pembelajaran daring di SD Negeri 1 Kedokan Agung, diantaranya adalah kurangnya antusias peserta didik dalam pembelajaran, peserta didik yang merasa bosan dan malas belajar, beberapa guru yang langsung memberikan tugas tanpa penjelasan materi terlebih dahulu, keterbatasan fasilitas karena masih ada beberapa wali murid yang tidak memiliki hp, masalah kuota internet dan jaringan internet yang tidak stabil, serta kurangnya kerjasama wali murid dengan peserta didik. Solusi yang ditempuh untuk menyelesaikan permasalahan pembelajaran daring di SD Negeri 1 Kedokan Agung, diantaranya adalah guru tetap memberikan bimbingan dan pendampingan pada peserta didik baik secara berkelompok atau individual, apabila ada orang tua atau siswa yang tidak memiliki handphone bisa datang langsung ke sekolah terkait informasi maupun penugasan, serta memberikan pengertian tentang pentingnya kerjasama orang tua dalam mengawasi putra-putrinya belajar dari rumah. 


\section{DAFTAR PUSTAKA}

Asmuni. (2020). Problematika Pembelajaran Daring di Masa Pandemi Covid-19 dan Solusi Pemecahannya. Jurnal Paedagogy, 7 (4), 281-288. doi:10.33394/jp.v714.2941

Bararah, I. (2017). Efektifitas Perencanaan Pembelajaran dalam Pembelajaran Pendidikan Agama Islam di Sekolah. Jurnal Mudarrisuna: Media Kajian Pendidikan Islam, 131-147. doi:10.22373/jm.v7i1.1913

Bilfaqih, Y., \& Qomarudin, M. N. (2015). Esensi Pengembangan Pembelajaran Daring. Yogyakarta: Deepublish.

Cahyati, N., \& Kusumah, R. (2020). Peran Orang Tua Dalam Menerapkan Pembelajaran Di Rumah Saat Pandemi Covid 19. Jurnal Golden Age, Universitas Hamranwadi, 4 (1), 152-159. doi:10.29408/goldenage.v4i01.2203

Dewi, W. A. (2020). Dampak Covid-19 Terhadap Implementasi Pembelajaran Daring di Sekolah Dasar. EDUKATIF: Jumal Ilmu Pendidikan, 2 (1), 55-61. doi:10.31004/edukatif.v2i1.89

Firman, \& Rahman, S. R. (2020). Pembelajaran Online di Tengah Pandemi Covid-19. Indonesian Journal of Educational Science (IJES), 2 (2), 81-89. doi:10.31605/ijes.v2i2.659

Imania, K. A., \& Bariah, S. K. (2019). Rancangan Pengembangan Instrumen Penilaian Pembelajaran Berbasis Daring. Jurnal PETIK, 5 (1), 31-47. doi:10.31980/jpetik.v5i1.445

Kuntarto, E. (2017). Keefetifan Model Pembelajaran Daring dalam Perkuliahan Bahasa Indonesia di Perguruan Tinggi. Journal Indonesian Language Education and Literature, 3 (1), 99-110. doi:10.24235/ileal.v3i1.1820

Rigianti, H. A. (2020). Kendala Pembelajaran Daring Guru Sekolah Dasar di Kabupaten Banjarnegara. Elementary School, 7 (2), 297-302. doi:10.31316/esjurnal.v7i2.768

Rupiah. (2020). Evaluasi Pelaksanaan Pembelajaran Daring daam masa Pandemi Covid-19 pada Tingkat Madrasah di Kabupaten Bengkulu Tengah. Sang Pencerah: Jurnal Ilmiah Universitas Muhammadiyah Buton, 7 (2), 179-188. doi:10.35326/pencerah.v7i2.1028

Sadikin, A., \& Hamidah, A. (2020). Pembelajaran Daring di Tengah Wabah Covid-19. BIODIK: Jurnal Ilmiah Pendidikan Biologi, 6 (2), 214-224. doi:10.22437/bio.v6i2.9759

Sopian, A. (2016). Tugas, Peran, dan Fungsi Guru Dalam Pendidikan. Raudhab Proud To Be Professionals: Jurnal Tarbiyah Islamiyah, 1 (1), 88-97. doi:10.48094/raudhah,v1i1.10

Sugiyono. (2020). Metode penelitian kuantitatif, kualitatif, dan R\&D . Bandung: Alfabeta.

Surat Edaran No. 4 Tabun 2020 Tentang Pelaksanaan Kebijakan Pendidikan Dalam Masa Darurat Penyebaran Corona VIrus Disease (COVID-19). Jakarta: KEMDIKBUD.

Surat Edaran Nomor 15 Tabun 2020 Tentang Pedoman Penyelenggaraan Belajar dari Rumah dalam Masa Darurat Penyebaran Covid-19. Jakarta: KEMDIKBUD.

Tafonao, T. (2018). Peranan Media Pembelajaran Dalam Meningkatkan Minat Belajar Mahasiswa. Jurnal Komunikasi Pendidikan, 2 (2), 103-114. doi:10.32585/jkp.v2i2.113

Undang-Undang Republik Indonesia Nomor 20 Tabun 2003 Tentang Sistem Pendidikan Nasional. Jakarta: DEPDIKNAS.

Wahyuningsih, K. S. (2021). Problematika Pembelajaran Daring di Masa Pandemi Covid-19 di SMA Dharma Praja Denpasar. Pangkaja Jumal Agama Hindu, 24 (1), 107-118. doi:10.25078/pkj.v24i1.2185 